\title{
The Effects of Relationship-Destroying Factors on Customer Relationships: Relationship Recovery as the Moderator
}

\author{
Hui-Chen Chang \\ National Taipei University \\ E-Mail: cjenny@gm.ntpu.edu.tw \\ Yi-Ching Tsai * \\ Shih Chien University \\ E-Mail: proworld@mail.kh.usc.edu.tw \\ Sheng-Yuan Hsu \\ National Taipei University \\ E-Mail: senyen@cht.com.tw
}

\begin{abstract}
The threshold for switching mobile phone numbers between different mobile communication service providers has largely decreased since the government lifted the ban on mobile phone number portability service. Users can convert their mobile communication service from their current provider to others while maintaining their existing phone numbers. The demand for mobile communication services has been increasing, along with the popular sales of smartphones and tablet PCs. However, more and more complaints have emerged in response to system service failures, employee service mistakes, and the sales promotion activities offered from competitors, which could destroy the trading relationship. These factors will lead to the customers' intentions of complaining and switching to another service provider.

This study aims to explore the relationship between destructive factors in trading relations, service providers' relationship-recovery policies, and the outcome of customer default. Empirical data were collected from mobile service users through online questionnaires. Using the general linear model (GLM) to test the research hypotheses, the results showed that (1) the relationship-destroying factors including service system failures and personnel service errors positively impact customers'
\end{abstract}

\footnotetext{
* correspondence author
} 
complaining and switching intentions and (2) the financial and psychological recovery policies might decrease the customers' complaining intention. Finally, this research also offers mobile communication services providers with strategic implications in customer relationship management.

Keywords: Relationship-destroying factors, relationship recovery, customer response

\section{INTRODUCTION}

Recently, smartphones have become very popular in Taiwan, resulting in a large number of sales. A number of mobile communication industries have actively started constructing a mobile network infrastructure and optimizing service quality. However, due to the frequent congestion of the mobile network, customer dissatisfaction has increased, affecting the buyer-seller relationship. Not only have customer complaints increased, but a number of customers are also switching mobile service providers. Under these circumstances, industries need to quickly raise the quality of the network connection, including upgrading their basic station and establishing Wi-Fi areas. Other than making the use of $\mathrm{Wi}-\mathrm{Fi}$ and $3 \mathrm{G}$ Internet connections more flexible, these service providers need to target customers with returning discounts or sales to decrease customer dissatisfaction.

In Taiwan, the demand for an increase in the Internet network connection in mobiles has grown at an alarming rate. According to the statistics provided by the National Communication Commission (NCC), the second quarter in 2011 saw the number of existing mobile phone numbers reach 28.29 million in Taiwan (an average of about 122.1 numbers per 100 people), marking an increase of 160,000 numbers compared to the previous quarter. In the same quarter last year, the total amount of existing numbers was 27.17 million (an average about 117.4 numbers per 100 people). Thus, over the span of one year, a growth of 1.12 million numbers occurred.

With an increase in sales in the mobile communication industry due to the popularity of the smartphones, operation income has increased; however, a problem emerged: broadband congestion. Far East Tone Telecommunications and Chung Hwa Telecom companies introduced wireless network sharing, which allowed people to access the Internet using other cell phones through user authorization. Thus, the online network service was not limited to just one person. The number of users was underestimated, and mobile $3 \mathrm{G}$ carriers were unable to catch up with the boost in customers, especially in metropolitan areas where many users gather at intensive construction areas. All these reasons give rise to the obstruction problem that $3 \mathrm{G}$ mobile network users face, which has become the target of criticism and complaints. 
The proliferation of 3G mobile Internet users caused Taiwan's mobile network companies to encounter the bandwidth congestion phenomenon; according to consumers, the Internet congestion problem has been worsening each day. Although the mobile communications industry has explained that a limitation exists in wireless transmission bandwidth-sharing features, the actual connection speed of mobile networks depends on factors such as location, users' hardware and software equipment, and usage status. However, consumers have still expressed dissatisfaction with the quality of mobile communications and are unimpressed that mobile service charges are higher in Taiwan than in South Korea.

Customers' complaints have increased, but they have not received a response from the mobile service providers. Whether customers express their opinions online or directly visit the store to convey the poor reception quality of the mobile carrier, they are unable to wait for satisfactory improvement in the system. On the other hand, other mobile communication network companies and online personnel service have sought to provide good quality international standards. However, during the service process, the information or communication gap might cause customer dissatisfaction, which might result in the demise of the buyer-seller relationship as well as complaints and switching intentions.

Past research has indicated that the cost of developing a relationship with a new customer is five times greater than maintaining one with an old customer (Peppers and Rogers, 1993). As a result, many companies have come to recognize the importance of maintaining relationships with existing customers. During the service delivery process, although it is important to attract new customers, service providers should also focus on how to maintain relationships with existing customers as well as increase repurchase intentions (Berry, 1983). Satisfied customers will recommend new customers through word of mouth, helping the company save promotion expenses. Thus, if the company could maintain positive relationships, there will be more opportunities to increase profits.

Using the preordering of the iPhone and flow process as an example, customers are usually notified of the dates for pre-ordering. However, due to the large online traffic jam during the pre-ordering period, the company's website bandwidth is inadequate for handling the flow or problems with the back-end database system, making it impossible to load. This situation caused many problems, such as the website being unable to be displayed on the screen. In addition, after pre-ordering, customers face large lines when they go to the store to pick up their iPhone, resulting in a lot of time and energy being wasted. Other problems that might arise stem from incompetent sales staff, poor service attitude and communication, or other service 
errors that could increase customer dissatisfaction and complaints and even result in customers changing service providers.

In the physical environment, the most direct contact that customers face is with humans. Service people and service scenarios are inconsistent, which might result in different service qualities being provided. Thus, if industries want to provide a perfect service, which is not easy, they might not be able to achieve customers' expectations of zero service errors or mistakes. According to Power, Driscoll, and Bohn (1992), if companies could improve customer retention by $20 \%$, company costs could be decreased by $20 \%$. The loss from customers leaving or the cost of follow-up services and remedial services cost more than if they had provided satisfactory service in the beginning. As service failures bring about a negative reputation, customers' complaints, and loss of customers, together they will result in large losses. An important problem facing companies today is how they provide satisfactory customer service remedies with limited resources and still achieve efficiency.

The mobile communication industry is a high operating cost industry. Competition is fierce, and companies need to be able to achieve customer satisfaction and recognition. They must be committed to creating customer value, communication, and delivery in the hopes of maintaining a positive customer relationship. From the provider's point of view, relationship-destroying factors are system failures, human errors, and the attractiveness of discounts provided by the competitors. One purpose of this study is to investigate whether these factors affect customers' complaints and switching intention. Service providers targeting the relationship-destroying factors using remedies to rescue the relationships will effectively decrease customer complaints and customer loss is the second purpose of this study.

Regarding the research background and motivation of this study, this research focuses on Taiwan's mobile communications as the subject of study, discussing how system failures, human mistakes, and competitor attractiveness might affect customer-buyer relationships and cause them to complain and seek another mobile service provider. In order to save and maintain relationships with customers, industries are looking to financial and psychological measures - whether they weaken the relationship-destruction factors, lessen customers' complaints, or change any switching intentions.

\section{LITERATURE REVIEW}

\section{Relationship-Destroying Factors}

Samaha et al. (2011) used longitudinal data to examine U.S. Fortune's 500 top companies, their interactive relationship with their distribution channels, and how 
companies build strong channel networks. She explored the causes of relationshipdestroying factors on both sides. Studies have shown that the unfair perception of channel dealers plays a key role as a "relationship poison" and directly harms the relationship between the channel dealers and the company. From the negative point of view, it increases conflict and speculation between both sides and has a negative impact on benefits by using contract management to manage channel relations. Studies have also examined the use of signing contracts similar to a double-edged sword; it could not only suppress conflicts and speculation, but also strengthen the perception of any unfairness (Samaha, Palmatier, and Dant, 2011).

The possible causes of relationship destruction between the company and its distribution channel could be due to speculative behavior, conflicts, perceived unfairness, and other factors. Reflecting on the relationship between companies and buyers, it is also important to have an in-depth understanding of the factors that destroy relationships. In the era of network communications, with the simple and fast flow of information, customers could share experiences via the Internet and any negative perceptions they have on a company's product or service. These could affect the decision making of other customers and returning visits.

Although the company is committed to providing high-quality products and services to meet customers' needs, they have periods in which they are unable to meet demands or have service defect errors, resulting in negative customer emotions and complaining behaviors; some have even considered switching service providers. Past studies by scholars have divided service failure into two sections: First, they have used longitudinal analyses to discuss how service failure began and the follow-up reaction. Second, they have divided service failure into different sections, including Flanagan (1954), who proposed the critical incident technique (CIT), which breaks down different industries and their service failures. CIT generally includes five steps: determine the target of the activity, generate plans and programs to collect data, collect info, analyze data, and explain data and form conclusions.

Bitner et al. (1994) researched three industries: hotels, restaurants, and airlines. They collected 699 cases of customer dissatisfaction and identified four types of service failures: (1) employees' reaction to service delivery system or product failures, (2) staff responses to customers' demands, (3) employees' spontaneous behavior, and (4) the behavior of customers with problems. Keaveney (1995) separated service failure into two categories. The first is the core service failure, which includes errors related to the service itself or other technical problems; the second is service encounter failures, including the errors that might occur during the interaction between first-line service personnel and customers, such as indifference, rude 
behavior, the failure to respond quickly to customers' demands, and a lack of expertise.

Many scholars divide service failures into process failures and outcome failures (Bitner, 1990; Hoffman, Kelley, and Rotalsky, 1995; Smith, Bolton, and Wagner, 1999). Process failure refers to the malfunction in the core service or products in the delivery service process. Outcome failures occur when customers receive the actual results (product or core services), but they do not meet the standards promised by the company (Smith et al., 1999). In other words, the customer does not receive the standard service they were meant to receive. If process failures occur, customers will have a loss during the delivery process. For example, when customers reach the hotel, the receptionist staff might deliver poor service (Smith et al., 1999). If outcome failure occurs, customers will suffer an economic loss. For example, if hotels overbook, it might result in customers not having a place to stay.

The attractiveness of competitive alternatives affects the relationship-destroying factors of buyer-seller relationships. It relates to the number of substitutes consumers are able to find in the market. When fewer choices are available in the market, if customers choose to leave their current service provider, the loss will be relatively high. Thus, companies can focus on enhancing their competitive position, as a method to attract customers (Ping, 1993). Empirical studies have indicated that, when there is a lack of competitive options, the possibility that customers will choose to terminate the current relationship with existing service providers is lower. Therefore, the attractiveness concept depends on how satisfied the customer is with alternatives and whether there are alternatives from which to choose. If customers do not know of any alternatives from which to choose or they do not have information as to whether they are more attractive or better than the existing trade relationship, they will still choose to maintain the current relationship, even if the customer is not satisfied with the service. In other words, the attractiveness of competitive alternatives describes the amount of satisfactory service they could obtain from other competitors and factors that attract customers to leave their existing service providers.

The subject of study in the current research is the users of mobile communication services. Common complaints from mobile users are the mistakes that employees make, including poor service quality from the first-line counter staff, employees who display unpleasant attitudes, poor service quality of telephone customer staff, and slow response from the customer service center. The other form of complaints relates to problems with the service system, which include poor mobile reception service, calls not getting through, slow internet connection, an inability to send out SMS, and incorrect billing amounts. Keaveney (1995) complied and classified poor network 
connection and slow Internet service as the problem of the core service failure. Poor service quality from first-line counter employees and customer service personnel is classified as service contact failure whereas service failures of different mobile communication service providers could result in the relationship being destroyed between the customer and service provider. Furthermore, because competitors constantly propose discount offerings to attract customers, it will result in customers having the intention to switch service providers. Overall, this study will discuss the failure of the service system of the mobile communication industry, employee service failure, and attractiveness of competitive alternatives as the three factors that destroy the customer relationship.

\section{Customer Response}

Managers of corporations focus primarily on whether customers turn to competitors, which will result in a loss of customers. Stauss and Friege (1999) pointed out that companies need to understand why their customers switch to other companies. Past studies have tried to define customer retention and the variety of different views, concluding that customer retention is a type of attitude performance. Scholars with this view have often placed customer retention and customer loyalty on the same classification as purchase intention or behavior. For example, Rust and Zahorik (1993) used customer loyalty as part of the logit choice model. Jones et al. (2000) explored the study of customer retention and viewed customer retention as repurchase intent. Bolton et al. (2000) researched the effect of loyalty programs and service experience on customer retention. From the repurchase behavior point of view, the current research will examine how customers decide on whether to maintain or terminate relationships with the credit card company.

Past research focuses on customers' possible reactions when they experience unsatisfactory service. Customers will choose to publicly voice their complaints or spread their unpleasant experience and negative comments to others through word of mouth. Research shows that a positive relationship exists between publicly voicing opinion and negative word of mouth; the possibility of negative word of mouth occurring is greater than the former. This study recommends that, to appeal to consumers, corporations and consumer protection groups must courageously make their voices heard to enable corporations to quickly identify problems and provide solutions to minimize the effect that negative word of mouth could have (Chelminski and Coulter, 2011). When customers are faced with service failures, they can pursue two types of immediate action: switching service and voicing complaints (Hunt, 1991). 


\section{Switching Intention}

Morgan and Hunt (1994) pointed out that, if service providers and customers have a prior relationship, it will significantly enhance the trust and commitment between them. Thus, when customers encounter an occasional service failure, they usually choose to believe that the service provider will provide a fair compensation to make up for the failure in the expected results. Over time, if customers continue to experience this kind of service, they are more unlikely to switch companies than those who have not experienced this before. Mattila (2001) and Hunt (1991) pointed out that, when customers want to terminate their relationship with the original service provider and switch to other companies, it is due to the behavior of the company. Reasons include seeking compensation, emotional catharsis, and assurances that those mistakes would not happen again.

Evaluating the switching intention occurs when the customer wants to leave the original service provider for another company and is lingering in the deciding stage, but is still unable to determine whether to end the relationship with the original company in the near future. This is suitable for cross-sectional studies (Hellier, Geursen, Carr, and Rickard, 2003; Hocutt, 1998; Jones, Mothersbaugh, and Beatty, 2000; Mittal and Lassar, 1998; Ping, 1994; Ping, 1995). The measurement of switching intention in this study is adopted from the research of Ping (1995).

\section{Complaining Intention}

Research has demonstrated that having a prior existing relationship will increase the psychological costs of customers that complain, but will reduce complaining intentions on any unsatisfactory services. One of the reasons why customers are unwilling to complain about service failures is because they have a prior relationship with the service provider and want to avoid directly facing them (Alicke et al., 1992). As the establishment of a relationship between companies and customers is based on trust, when customers complain to the service providers, it could be interpreted as a loss of trust in the company. A customer's past experiences will increase their trust in the company. In addition, when companies encourage customers to speak out about any dissatisfaction and concerns, they will expect their issues to be solved. However, once the customer has accumulated long-term dissatisfaction against the company, they will be motivated to retaliate (Morgan and Hunt, 1994).

Customers' complaints are one way that customers express disapproval. They consist of four types: complaining to their families, complaining to friends, complaining to a third party, and complaining to the government authorities. This study will define customers' switching intention and complaining intention as 
customer response and will discuss their results. The developed hypothesis is as follows:

$\mathrm{H}_{1}$ : Relationship-destroying factors have a positive relationship on customerswitching intention.

$\mathrm{H}_{1 \mathrm{a}}$ : System errors have a positive relationship on customer switching intention.

$\mathrm{H}_{1 \mathrm{~b}}$ : Personnel mistakes have a positive relationship on customer switching intention.

$\mathrm{H}_{1 \mathrm{c}}$ : Attractiveness of competitive alternatives has a positive relationship on customer switching intention.

$\mathrm{H}_{2}$ : Relationship-destroying factors have a positive relationship on customer complaints.

$\mathrm{H}_{2 \mathrm{a}}$ : System failures have a positive relationship on customer complaints.

$\mathrm{H}_{2 \mathrm{~b}}$ : Personnel mistakes have a positive relationship on customer complaints.

$\mathrm{H}_{2 \mathrm{c}}$ : Attractiveness of competitors has a positive relationship on customer complaints.

\section{Relationship Recovery}

Service recovery practices create a type of exchange, where such an exchange is due to service errors leading to a loss in customer experience and how the company compensates for such errors (Smith et al., 1999). The purpose of service recovery is to reverse the impression customers have on the company, increase customer satisfaction, and anticipate that in the end they could maintain a long-standing relationship with customers. Hart, Heskett, and Sasser (1990) discovered the processes of an effective remedy, including measuring cost, breaking the silence, remedying expectation, acting swiftly, providing staff training, assigning power to first-line employees, and ending the cycle. Tax and Brown (1998) proposed a type of service quality recovery process that includes four phases: confirm service failure, solve customer problems, focus on service failure and start to communicate and classify, and integrate information and improve overall service.

Overall equality mixes up a variety of fair value perceptions, which contain the results of service compensation and the entire service recovery process. Smith et al. (1999) pointed out that service failure research generally does not cover equality fully, indicating that it limits the customer satisfaction model from having a good explanation. In the past, when measuring the fairness of the service recovery process, most customers have used their own service failure experiences as the reference point (Smith et al., 1999). In fact, customers who measure fairness base perception on three 
angles: procedural fairness, which relates to the service dispute and resolution process, customer experience, and overall fairness; the distribution of fairness, which describes the resolution customers receive at the end; and fair interaction, which refers to whether customers are treated with respect and courtesy during the service recovery process and the results.

In terms of theory, although a variety of service failures exist, customers continue to blame service failures as problems that the company could control; therefore, when service failures have to do with service providers, they should take the initiative and apologize to the customer (Folkes, 1984). Service varies and is unable to be divided, making it very difficult to avoid service failures during the service process (Tax and Brown, 1998). When customers encounter service failures, they expect the companies to provide good remedies (McCollough, Berry, and Yadav, 2000). It is worth noting that, when customers feel unsatisfied with the service recovery, it will increase dissatisfaction up to the point where customers will switch companies (Keaveney, 1995). Therefore, Kelley, Hoffman, and Davis (1993) asserted that companies should admit fault and be prepared for relationship recovery efforts to deal with customers' responses to service failures.

Previous studies on service failures used experiments involving apologies and discounts (Boshoff, 1997), refunds (Bitner, 1990; Smith and Bolton, 1998), or service redo as different recovery efforts (Bitner, 1990). Many kinds of service remedies exist. Hart et al. (1990) divided them into apology, compensation, and response. Smith et al. (1999) categorized service remedy as apology, compensation, speedy remedy, or corporation remedy. Schweikhart, Strasser, and Kennedy (1993) analyzed service remedy by studying the medical industry and classified remedy into two levels: actual level, which is the direct compensation for the customer's losses (e.g., free service or free products), and psychological level, which is the use of apology and explanation to eliminate customer dissatisfaction. Miller, Craighead, and Karwan (2000) relied on tangible compensation, dividing it into tangible compensation and psychological compensation. Tangible compensation refers to the tangible and actual recovery effort, which reimburses customers for service failure resulting in customer loss or convenience loss or provides a value-added compensation. Psychological compensation includes apology and explanations, which could directly improve customer dissatisfaction in a very easy and economic way, but caution needs to be undertaken to ensure that it will not result in opposite results and give rise to the customer's negative emotions.

Based on the previous research, this study will adopt the service failures of the mobile communication industry and attractiveness of competitive alternatives as 
relationship-destroying factors. In addition, the service remedies provided by companies are relationship-recovery efforts, which will be divided into financial compensation or psychological compensation. These two types of relationship remedies are the company's response when they face a damaged relationship with customers. The leads to the development of the following hypotheses:

$\mathrm{H}_{3}$ : Financial types of remedy have a negative moderating effect on the relationship-destroying factors and switching intent.

$\mathrm{H}_{4}$ : Financial types of remedy have a negative moderating effect on relationshipdestroying factors and complaint intention.

$\mathrm{H}_{5}$ : Psychological types of remedy have a negative moderating effect on the relationship-destroying factors and switching intent.

$\mathrm{H}_{6}$ : Psychological types of remedy have a negative moderating effect on relationship-destroying factors and complaint intention.

\section{Research Framework}

\section{METHOD}

This research discusses the formation of the seller-customer relationship in the mobile communication industry, including how factors that destroy relationships affect customers' responses and the result and interference of companies that use relationship remedies and switching barriers. The recovery process is divided into financial and psychological types. This research explains how they interfere with customers' responses to switching companies and complaint intention and seeks to understand which factors destroy the relationship and whether remedies could have an effect on customer response. In addition, this study will divide switching barriers into social and economic types to explain how these two barriers interfere with switching and the complaining intention and to understand if the switching barriers of relationship-destroying factors will affect customer response behavior. The research framework and hypothesis are shown in Figure1.

\section{Variables and Measurement}

Relationship-destroying factors relate to the service failures of the service providers, human mistakes, and attractiveness of competitive alternatives and other factors. These results in negative perceptions result in damage to the buyer-seller relationships. The relationship-destroying factors of this research refer to Keaveney's (1995) two proposed factors: system failure and employee failure. We also refer to "the attractiveness of competitive alternatives" that Jones et al. (2000) proposed and the 
construction of three dimensions. This research refers to the fourteen measurement factors proposed by Brady and Cronin (2001), Hui et al. (2004), Jones et al. (2000), Ping (1993), and Patterson and Smith (2003).

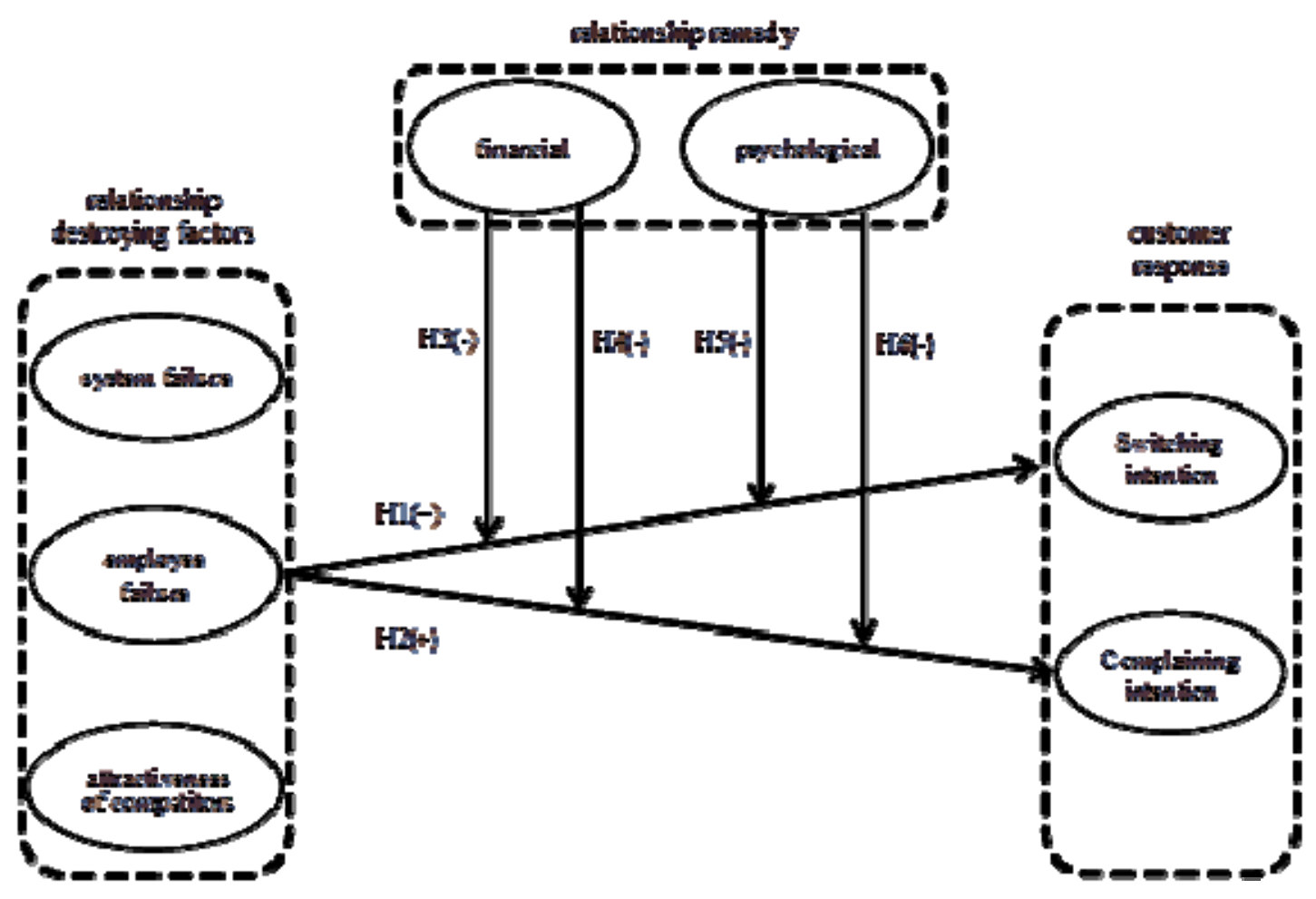

Figure 1 Research framework

Relationship remedy relates to the effect and interference that companies' financial type of remedy have on relationship-destroying factors with customer switching intentions. It also discusses the effect and interference psychological remedies provided by companies have on relationship-destroying factors with customer complaints, including measuring the effect that the relationship remedy has on relationship-destroying factors and customer reactions. This research refers to the remedy classification (psychological and tangible) used by Schweikhart et al. (1993) and Miller et al. (2000) and measures the financial alternative construction against relationship remedies. This research refers to the 11 measurement factors proposed by Boshoff (1997), Bitner (1990), Smith et al. (1999), and Baker et al. (2008).

Companies face a variety of reactions and behaviors from customers and need to have a deeper understand when customers have complaint behavior or consider switching companies, as it will result in a substantial loss and damage the relationship 
between the customer and the buyer. Thirteen measurement factors of customer response in this research are modified from Ping (1995) and Kalamas et al. (2008).

\section{Research Object and Sampling}

This research chose to use Taiwan's mobile and 3G mobile Internet users as the target population, using questionnaires to collect data on how they view relationshipdestroying factors, relationship remedy, and customer response. Online surveys were used to collect data as well.

\section{Measurement Model}

\section{RESULTS}

This study first examined the reliability and the convergent and discriminant validity of the main constructs by conducting a confirmatory factor analysis (CFA) using LISREL 8.51 before testing the research hypotheses. The fit of the CFA is acceptable, with $\chi^{2}=1755.23, \mathrm{df}=704, \chi 2 / \mathrm{df}=2.49$, GFI $=0.82, \mathrm{AGFI}=0.79$, CFI $=0.91$, and RMSEA = 0.061 (Hair, Anderson, Tatham, and Black, 1998).

Reliability assessment uses composite reliability (CR) estimates. The values of composite reliability ranged from 0.86 to 0.94 , demonstrating good reliability. Factor loadings' significance and average variance extracted (AVE) were used to assess convergent validity. All factor loadings are higher than 0.71 and significant $(\mathrm{p}<0.01)$. Average variances extracted are above the recommended 0.5 cut-off value (ranging from 0.68 to 0.81 ), indicating the measurement's convergent validity (Bagozzi and Yi, 1988). In addition, this measurement ensures the discriminant validity because the square root of AVEs in diagonal are greater than the correlation coefficients in the offdiagonal (Fornell and Larcker, 1981) listed in Table 1.

\section{Hypothesis Testing}

This study uses the general linear model (GLM) to test the research hypotheses. As Table 2 indicates, this research verified that the service failures of the mobile communication industry have a significant positive effect on customer complaints and switching intentions, but attractiveness of competitive alternatives does not have a significant effect on customer complaints or switching intentions. On the other hand, if the mobile communication industry uses financial and psychological relationship remedial factors, it will have no significant interference on customer switching intention, but might effectively reduce customer complaints. All the results of the hypothesis testing in this research are summarized in Table 3. 
Table 1 Correlations and the Square Roots of the Average Variance Extracted

\begin{tabular}{cccccccc}
\hline & SF & EF & CA & FR & PR & SI & CI \\
\hline SF & $\mathbf{0 . 8 2}$ & & & & & & \\
EF & 0.66 & $\mathbf{0 . 8 5}$ & & & & & \\
CA & 0.22 & 0.25 & $\mathbf{0 . 8 5}$ & & & & \\
FR & 0.14 & 0.20 & 0.01 & $\mathbf{0 . 8 7}$ & & & \\
PR & 0.06 & 0.08 & 0.01 & 0.82 & $\mathbf{0 . 8 4}$ & & \\
SI & 0.62 & 0.47 & 0.15 & 0.09 & 0.01 & $\mathbf{0 . 8 4}$ & \\
CI & 0.26 & 0.35 & 0.02 & 0.35 & 0.39 & 0.30 & $\mathbf{0 . 9 0}$ \\
\hline
\end{tabular}

$\mathrm{SF}=$ system failure, $\mathrm{EF}=$ employee failure, $\mathrm{CA}=$ attractiveness of competitors, $\mathrm{FR}=$ financial remedy, $\mathrm{PR}=$ psychological remedy, $\mathrm{SI}=$ switching intention, $\mathrm{CI}=$ complaining intention.

Numbers in bold refers to AVEs

Table 2 Results of Hypothesis Tested

\begin{tabular}{|c|c|c|c|c|c|c|c|c|}
\hline \multirow{2}{*}{$\begin{array}{l}\text { Hypothesis } \\
\mathrm{R}^{2}\end{array}$} & \multirow[t]{2}{*}{ Predictor } & \multicolumn{3}{|c|}{ DV: SI } & \multicolumn{4}{|c|}{ DV: CI } \\
\hline & & $\beta$ & & & $\mathrm{R}^{2}$ & $\beta$ & & $\mathrm{F}$ \\
\hline \multicolumn{9}{|c|}{ FR as the moderator } \\
\hline H1a & SF & $0.400^{* * *}$ & $11.43^{* *}$ & 0.430 & $0.10^{+}$ & $4.23^{+}$ & 0.219 & \\
\hline $\mathrm{H} 1 \mathrm{~b}$ & $\mathrm{EF}$ & $0.21^{* * *}$ & & & $0.36^{* * *}$ & & & \\
\hline $\mathrm{H} 1 \mathrm{c}$ & $\mathrm{CA}$ & 0.02 & & & -0.01 & & & \\
\hline \multirow[t]{3}{*}{$\mathrm{H} 3, \mathrm{H} 4$} & $\mathrm{SF}^{*} \mathrm{FR}$ & $-0.07^{*}$ & $10.44^{* *}$ & 0.438 & 0.002 & $5.23^{+}$ & 0.281 & \\
\hline & $\mathrm{EF}^{*} \mathrm{FR}$ & 0.02 & & & 0.02 & & & \\
\hline & $\mathrm{CA} * \mathrm{FR}$ & $0.04^{*}$ & & & $0.05^{*}$ & & & \\
\hline
\end{tabular}

$\mathrm{PR}$ as the moderator

\begin{tabular}{llllllll}
\hline H2a & SF & $0.40^{* * *}$ & $11.43^{* *}$ & 0.430 & $0.10^{+}$ & $4.23^{+}$ & 0.219 \\
H2b & EF & $0.21^{* * *}$ & & & $0.36^{* * *}$ & & \\
H2c & CA & 0.02 & & & -0.01 & & \\
H5, H6 & SF*FR & -0.02 & $10.28^{* *}$ & 0.434 & -0.006 & $5.62^{* * *}$ & 0.296 \\
& EF*FR & -0.02 & & & 0.01 & & \\
& CA*FR & 0.02 & & & $0.06^{*}$ & & \\
& & & & &
\end{tabular}

${ }^{+}: \mathrm{p}<0.1,{ }^{*}: \mathrm{p}<0.05,{ }^{* *}: \mathrm{p}<0.01,{ }^{* * *}: \mathrm{p}<0.001$ 
Table 3 Results of Hypothesis Tested

\begin{tabular}{|c|l|}
\hline \multicolumn{1}{|c|}{ Hypothesis } & \multicolumn{1}{|c|}{ Result } \\
\hline $\begin{array}{c}\mathrm{H}_{1}: \text { Relationship destroying factors have a positive relationship on } \\
\text { customer switching intention }\end{array}$ & $\begin{array}{l}\text { Partially } \\
\text { Supported }\end{array}$ \\
\hline $\begin{array}{c}\mathrm{H}_{1 \mathrm{a}}: \text { System errors have a positive relationship on customer } \\
\text { switching intention }\end{array}$ & Supported \\
\hline $\begin{array}{l}\mathrm{H}_{1 \mathrm{~b}}: \text { Personnel mistakes have a positive relationship on customer } \\
\text { switching intention }\end{array}$ & Supported \\
\hline $\begin{array}{l}\mathrm{H}_{1 \mathrm{c}}: \text { Attractiveness of competitive alternatives has a positive } \\
\text { relationship on customer switching intention }\end{array}$ & Not Supported \\
\hline $\begin{array}{l}\mathrm{H}_{2}: \text { Relationship destroying factors have a positive relationship on } \\
\text { customer complaint intention }\end{array}$ & $\begin{array}{l}\text { Partially } \\
\text { Supported }\end{array}$ \\
\hline $\begin{array}{l}\mathrm{H}_{2 \mathrm{a}}: \text { System failures have a positive relationship on customer } \\
\text { complaint intention }\end{array}$ & Supported \\
\hline $\begin{array}{l}\mathrm{H}_{2 \mathrm{~b}}: \text { Personnel mistakes have a positive relationship on customer } \\
\text { complaint intention }\end{array}$ & Supported \\
\hline $\begin{array}{l}\mathrm{H}_{2 \mathrm{c}}: \text { Attractiveness of competitors has a positive relationship on } \\
\text { customer complaint intention }\end{array}$ & Not Supported \\
\hline $\begin{array}{l}\mathrm{H}_{3}: \text { Financial types of remedy has a negative moderating effect on } \\
\text { the relationship destroying factors and switching intention }\end{array}$ & Not Supported \\
\hline $\begin{array}{l}\mathrm{H}_{4}: \text { Financial types of remedy has a negative moderating effect on } \\
\text { relationship destroying factors and complaint intention }\end{array}$ & Supported \\
\hline $\begin{array}{l}\mathrm{H}_{5}: \text { Psychological types of remedy has a negative moderating } \\
\text { effect on the relationship destroying factors and switching } \\
\text { intention }\end{array}$ & Not supported \\
\hline $\begin{array}{l}\mathrm{H}_{6}: \text { Psychological types of remedy has a negative moderating } \\
\text { intention }\end{array}$ & Supported \\
\hline
\end{tabular}

\section{CONCLUSION}

When service systems and employee service result in mistakes and are unable to meet customers' needs, it is common for customers to become dissatisfied. Such a problem has occurred in the operating system of mobile communication companies; thus, changes need to be made through a fundamental approach to the construction of the hardware and software system, improvements in the quality of service and changes in employee training, and the gathering of market information to respond quickly to changes in customers' demands.

Mobile communication industries cannot always rely on remedial actions, including financial and psychological measures to compensate for the destruction of customer relationships or rely on switching barriers to block the attractiveness of competitive alternatives and reduce switching intentions. Otherwise, although 
customers receive relationship remedy or are unable to change mobile carriers and continue to maintain the rent relationship with the current mobile communication industry, they might continue to complain and pass negative word of mouth. As a result, it will have a negative effect on the company and could potentially deteriorate long-term relationship on both sides.

Financial and psychological relationship remedy could effectively reduce customer complaints and enhance the long-term relationship between both sides, thereby decreasing the negative word of mouth. The mobile communications industry should develop a standard comprehensive process of remedial relationship.

Establishing a routine and standardized remedial system and process could highly and effectively release dissatisfied emotions as well as establish a basis for problem solving. Not only could it prevent negative word of mouth, but it could also contribute to the long-term corporate image. These routine, standardized operating procedures consist of establishing customer service lines, an Internet message system, first-line employees, customer relationship management team telephone greetings, and other interactive channels or designing financial remedy compensation. All these efforts allow dissatisfied customers to give a suitable catharsis and solution, effectively reducing customer complaint behavior.

In conclusion, competition in the mobile communication industry is perceived as a war among overall service quality, the industry's system service errors, and employee errors, which will directly lead to customer complaints and switching intentions, destroying the industry efforts - a key point in determining whether they will win or be defeated in the market. Other competitive strategies, such as using financial or psychological relationship remedy measures, might not decrease switching intentions, but could effectively decrease customer complaints. Industries could consider whether they should establish remedy strategies with the customers.

\section{RERERENCE}

Alicke, M. D., Braun, J. C., Glor, J. E., Klotz, M. L., Magee, J., and Sederhoim, H. (1992). Complaining behavior in social interaction. Personality and Social Psychology Bulletin, 18(3), 286-295. http://dx.doi.org/10.1177/0146167292183004

Bagozzi, R. P. and Yi, Y. (1988). On the evaluation of structural equation models. Journal of the Academy of Marketing Science, 16(1), 74-94. http://dx.doi.org/10.1007/BF02723327

Baker, T., Meyer, T., and Johnson, J. (2008). Individual differences in perceptions of service failure and recovery: the role of race and discriminatory bias. Journal of 
the Academy of Marketing Science, 36(4), 552-564. http://dx.doi.org/10.1007/s11747-008-0089-x

Berry, L. L. (1983). Relationship Marketing. In Emerging Perspectives on Services Marketing, Leonard L. Berry, G. Lynn Shostack, and Gregory Upah, eds. Chicago, IL: American Marketing Association, 25-28. http://dx.doi.org/10.1300/J366v01n01_05

Bitner, M. J. (1990). Evaluating service encounters: the effects of physical surroundings and employee responses. The Journal of Marketing, 54(2), 69-82. http://dx.doi.org/10.2307/1251871

Bitner, M. J., Booms, B. H., and Mohr, L. A. (1994). Critical service encounters: the employee's viewpoint. The Journal of Marketing, 58(10), 95-106. http://dx.doi.org/10.2307/1251919

Bolton, R. N., Kannan, P. K., and Bramlett, M. D. (2000). Implications of Loyalty Program Membership and Service Experiences for Customer Retention and Value. Journal of the Academy of Marketing Science, 28 (1), 95-108. http://dx.doi.org/10.1177/0092070300281009

Boshoff, C. (1997). An experimental study of service recovery options. International Journal of Service Industry Management, 8(2), 110-130. http://dx.doi.org/10.1108/09564239710166245

Brady, M. K. and Cronin Jr, J. J. (2001). Some new thoughts on conceptualizing perceived service quality: a hierarchical approach. The Journal of Marketing, 65(3), 34-49. http://dx.doi.org/10.1509/jmkg.65.3.34.18334

Chelminski, P. and Coulter, R. A. (2011). An examination of consumer advocacy and complaining behavior in the context of service failure. Journal of Services Marketing, 25(5), 361-370. http://dx.doi.org/10.1108/08876041111149711

Flanagan, J. C. (1954). The critical incident technique. Psychological Bulletin, 51(4), 327. http://dx.doi.org/10.1037/h0061470

Folkes, V. S. (1984). Consumer Reactions to Product Failure: An Attributional Approach. Journal of Consumer Research, 10(3), 398-409. http://dx.doi.org/10.1086/208978

Fornell, C. R. and Larcker, F. F. (1981). Structural Equation Models with Unobservable Variables and Measurement Error. Journal of Marketing Research, 18, 39-51. http://dx.doi.org/10.2307/3151312

Hair, J. F., Anderson, R. E., Tatham, R. L., and Black, W. C. (1998). Multivariate Data Analysis (5th ed.). Prentice Hall, Uppersaddle River, NJ.

Hart, C. W. L., Heskett, J. L., and Sasser, W. E. (1990). The profitable art of service recovery. Harvard Business Review, 68(4), 148-156. 
Hellier, P. K., Geursen, G. M., Carr, R. A., and Rickard, J. A. (2003). Customer Repurchase Intention: A General Structural Equation Model. European Journal of Marketing, 37(11), 1762-1800.

http://dx.doi.org/10.1108/03090560310495456

Hocutt, M. A. (1998). Relationship dissolution model: Antecedents of relationship commitment and the likelihood of dissolving a relationship. International Journal of Service Industry Management, 9(2), 189-200. http://dx.doi.org/10.1108/09564239810210541

Hoffman, K. D., Kelley, S. W., and Rotalsky, H. M. (1995). Tracking service failures and employee recovery efforts. Journal of Services Marketing, 9(2), 49-61. http://dx.doi.org/10.1108/08876049510086017

Hui, M. K., Xiande, Z., Xiucheng, F., and Kevin, A. (2004). When does the service process matter? A test of two competing theories. Journal of consumer Research, 31(2), 465-475. http://dx.doi.org/10.1086/422123

Hunt, S. D. (1991). Positivism and paradigm dominance in consumer research: Toward critical pluralism and rapprochement. Journal of Consumer Research, 32-44. http://dx.doi.org/10.1086/209238

Jones, M. A., Mothersbaugh, D. L., and Beatty, S. E. (2000). Switching barriers and repurchase intentions in services. Journal of Retailing, 76(2), 259-274. http://dx.doi.org/10.1016/S0022-4359(00)00024-5

Kalamas, M., Laroche, M., and Makdessian, L. (2008). Reaching the boiling point: Consumers' negative affective reactions to firm-attributed service failures. Journal of Business Research, 61 (8), 813-824. http://dx.doi.org/10.1016/j.jbusres.2007.09.008

Keaveney, S. M. (1995). Customer switching behavior in service industries: An exploratory study. The Journal of Marketing, 59(2), 71-82. http://dx.doi.org/10.2307/1252074

Kelley, S. W., Hoffman, K. D., and Davis, M. A. (1993). A typology of retail failures and recoveries. Journal of Retailing, 69(4), 429-452. http://dx.doi.org/10.1016/0022-4359(93)90016-C

Mattila, A.S. (2001). Emotional Bonding and Restaurant Loyalty. Cornell Hotel and $\begin{array}{llll}\text { Restaurant } & \text { Administration } & \text { Quarterly, } & \text { 42(6), }\end{array}$ http://dx.doi.org/10.1177/0010880401426009

McCollough, M. A., Berry, L. L., and Yadav, M. S. (2000). An empirical investigation of customer satisfaction after service failure and recovery. Journal of Service Research, 3(2), 121-137. http://dx.doi.org/10.1177/109467050032002 
Miller, J. L., Craighead, C. W., and Karwan, K. R. (2000). Service recovery: a framework and empirical investigation. Journal of Operations Management,18(4), 387-400. http://dx.doi.org/10.1016/S0272-6963(00)00032-2

Mittal B. and Lassar, W.M. (1998). Why Do Customers Switch? The Dynamics of Satisfaction versus Loyalty. The Journal of Services Marketing, 12(3), 177-194. http://dx.doi.org/10.1108/08876049810219502

Morgan R. M. and Hunt, S. D. (1994). The commitment-trust theory of relationship marketing. The Journal of Marketing, 58(3), 20-38. http://dx.doi.org/10.2307/1252308

Patterson, P. G. and Smith, T. (2003). A cross-cultural study of switching barriers and propensity to stay with service providers. Journal of Retailing, 79(2), 107-120. http://dx.doi.org/10.1016/S0022-4359(03)00009-5

Peppers, D., and Rogers, M. (1993). The One-to-One Future: Building Relationships One Customer at a Time. Doubleday, Garden City, NY.

Ping, R. A. (1993). The effects of satisfaction and structural constraints on retailer exiting, voice, loyalty, opportunism, and neglect. Journal of Retailing, 69(3), 320-352. http://dx.doi.org/10.1016/0022-4359(93)90010-G

Ping, R. A. (1994). Does satisfaction moderate the association between alternative attractiveness and exist intention in a marketing channel? Journal of the Academy of Marketing Science, 22, 364-371. http://dx.doi.org/10.1177/0092070394224005

Ping, R. A. (1995). Some uninvestigated antecedents of retailer exit intention. Journal of Business Research, 34(3), 171-180. http://dx.doi.org/10.1016/01482963(94)00079-T

Power, C., Driscoll L., and Bohn, E. (1992). Smart selling: how companies are winning over today's tougher customer. Business Week, 3277(3), 46.

Rust, R. T. and Zahorik, A. J. (1993). Customer Satisfaction, Customer Retention and $\begin{array}{llllll}\text { Market Share. Journal of Retailing, } 69 & \text { (2), 193-215. }\end{array}$ http://dx.doi.org/10.1016/0022-4359(93)90003-2

Samaha, S. A., Palmatier, R. W., and Dant, R. P. (2011). Poisoning Relationships: Perceived Unfairness in Channels of Distribution. Journal of Marketing, 75(3), 99-117. http://dx.doi.org/10.1509/jmkg.75.3.99

Schweikhart, S. B., Strasser, S., and Kennedy, M. R. (1993). Service recovery in health services organizations. Hospital \& Health Services Administration, 38(1), 3. 
Smith, A. K. and Bolton, R. N. (1998). An experimental investigation of customer reactions to service failure and recovery encounters. Journal of Service Research, 1(1), 65-81. http://dx.doi.org/10.1177/109467059800100106

Smith, A. K., Bolton, R. N., and Wagner, J. A. (1999). Model of customer satisfaction with service encounters involving failure and recovery. Journal of Marketing Research, 36(3), 356-372. http://dx.doi.org/10.2307/3152082

Stauss, B. and Friege, C. (1999). Regaining Service Customers. Journal of Service Research, 1 (4), 347-361. http://dx.doi.org/10.1177/109467059914006

Tax, S. S. and Brown, S. W. (1998). Recovering and learning from service failure. Sloan Management Review, 40(1), 75-88. 